\title{
Płuczki lateksowo-glinowe do przewiercania niestabilnych formacji łupkowych
}

\begin{abstract}
Niestabilność otworu jest jednym z poważniejszych problemów w przemyśle wiertniczym i decydującym czynnikiem wpływającym na zwiększenie kosztów wiercenia. Pomimo postępu technologii wiercenia niestabilność łupków nadal stanowi wyzwanie, w szczególności podczas wiercenia długich odcinków horyzontalnych otworu. W celu zapobiegania niekorzystnym zjawiskom w składach płuczek wiertniczych wykorzystuje się środki chemiczne pełniące funkcję inhibitorów hydratacji skał ilasto-łupkowych. W niektórych przypadkach nawet zastosowanie skutecznych inhibitorów hydratacji skał łupkowych nie zabezpiecza przed zmniejszeniem ich stabilności wskutek działania zbyt wysokiego ciśnienia porowego PPT. Zmniejszenie ciśnienia, pod jakim filtrat z płuczki wiertniczej wnika w pory przewiercanych skał, jest jednym z najważniejszych czynników decydujących o zachowaniu stabilności otworu. W artykule przedstawiono badania laboratoryjne nad opracowaniem składu płuczki wiertniczej zdolnej do tworzenia w przewiercanych niestabilnych i sypliwych formacjach łupkowych szczelnego i odkształcalnego osadu filtracyjnego, przeciwdziałającego wnikaniu filtratu płuczkowego i ograniczającego wzrost ciśnienia porowego przewiercanej formacji skalnej. Stabilizacja przewiercanych formacji łupkowych realizowana będzie poprzez zastosowanie w składzie płuczki specjalnego zestawu środków chemicznych, obejmującego odpowiednio dobrane połączenie związków glinu z różnymi rodzajami lateksu i polimerami.
\end{abstract}

Słowa kluczowe: płuczka wiertnicza, lateks, kompleks glinowy, niestabilność otworu.

\section{Latex-aluminum muds for instable shale formations drilling}

Drilling hole instability is one of the major problems in the drilling industry and the decisive factor in increasing the cost of drilling. Despite the progress of drilling technology, shale instability continues to be a challenge in the drilling industry, particularly during long horizontal drilling. In order to prevent unfavorable phenomena in the compositions of drilling muds, chemical substances acting as hydration inhibitors of shales are used. In some cases, even the use of effective shale hydration inhibitors does not prevent them from decreasing their stability due to too high pore pressure "PPT". Reducing the pressure at which the filtrate from the drilling fluid penetrates the pores of the drilled rocks, is one of the most important factors in maintaining the stability of the drilling hole. In this paper is presented, a laboratory study on the development of a drilling fluid composition capable of forming seal and deformable filter cake preventing the penetration of the mud filtrate and limiting the increase of the pore pressure of the drilled rock formation. Stabilization of drilled shale formations will be accomplished through the use of a special set of chemicals in the mud, including a combination of aluminum compounds with various types of latex and polymers.

Key words: drilling mud, latex, aluminum complex, hole instability.

\section{Wprowadzenie}

Podczas wiercenia otworu około $75 \%$ przewierconych formacji stanowią łupki, które w ponad 90\% są przyczyną większości problemów związanych z niestabilnością otworu. Niestabilność otworu jest jednym z poważniejszych problemów w przemyśle wiertniczym oraz decydującym czynnikiem wpływającym na zwiększenie kosztów wiercenia. Pomimo postępu technologii wiercenia niestabilność łupków nadal stanowi wyzwanie, w szczególności podczas wiercenia długich odcinków horyzontalnych otworu. Dobór odpowiednich właściwości inhibicyjnych płuczek wiertniczych do przewiercania warstw ilasto-łupkowych ma duże znaczenie ze względu na ich skłonność do hydratacji pod wpływem wody / filtratu płuczkowego. W wyniku niekontrolowanej hydratacji wywołanej fizykochemicznym oddziaływaniem filtratu 
z płuczki wiertniczej na skały ilasto-łupkowe zostaje naruszona struktura krystaliczna minerałów, a tym samym równowaga statyczna skał w otworze wiertniczym $[1,2,14,20]$.

Analizując problemy związane ze zjawiskami hydratacji skał ilasto-łupkowych w aspekcie stateczności ścian otworu, należy uwzględnić również ciśnienie powstające w porach skał ilasto-łupkowych w wyniku ich kontaktu z filtratem płuczkowym. Powiększanie objętości skały w wyniku adsorpcji wody z filtratu płuczkowego prowadzi do wzrostu ciśnienia. Skały ilasto-łupkowe w wyniku adsorpcji pewnej objętości wody dążą do zwiększania swojej objętości, jednak ze względu na nacisk nadkładu i tym samym brak możliwości swobodnego ich rozszerzania się proces ten odbywa się kosztem zmniejszania się średnicy otworu, a zatem związany jest ze wzrostem ciśnienia porowego o wielkość ciśnienia pęcznienia. Przy rozpatrywaniu wielkości ciśnienia pęcznienia należy również wziąć pod uwagę wpływ ciśnień osmotycznych i kapilarnych. Trzeba podkreślić, że nie ma możliwości szybkiego wyrównywania się ciśnień pomiędzy skałą ilastą a płuczką wiertniczą ze względu na bardzo małą przepuszczalność skał łupkowych $[2,3,10,11,14,17]$.

Zachodzące procesy w skałach łupkowych wywołane fizykochemicznym oddziaływaniem filtratu z nieodpowiednio zastosowanej płuczki wiertniczej powodują naruszenie stabilności ścian otworu. Przeciwdziałać tym procesom można poprzez dobór odpowiedniej mineralizacji płuczki wiertniczej w odniesieniu do mineralizacji wody w skale, umożliwiającej obniżenie wielkości sił osmotycznych, lub poprzez zastosowanie polimerów zapobiegających hydratacji powierzchniowej cząstek skał.

Jednym ze sposobów poprawy stabilności formacji łupkowych, przy stosowaniu wodnodyspersyjnych płuczek wiertniczych, jest przeciwdziałanie wnikaniu filtratu płuczkowego do matrycy skały, co można osiągnąć poprzez chemiczną modyfikację składu płuczki wiertniczej lub fizyczne uszczelnianie porów i szczelin łupków specjalnymi materiałami.

Ostatnio zaproponowano wiele rozwiązań stabilizowania formacji łupkowych, między innymi stosowanie w składach płuczek wiertniczych węglanu wapnia o różnym stopniu granulacji, asfaltenów, poliglikoli czy akrylanów $[3,5,13,17,20]$. Badania prowadzone $\mathrm{w}$ celu ograniczenia ciśnienia porowego skał łupkowych wykazały, że stosowane środki w płuczkach wiertniczych, takie jak zmodyfikowany węglan wapnia, akrylany i polimery, nie zapobiegają wzrostowi ciśnienia porowego z uwagi na zbyt duże rozmiary, niedostosowane do wielkości porów skały łupkowej $(<0,01 \mu \mathrm{m})$. W celu zmniejszenia ciśnienia porowego coraz częściej do stabilizacji skał łupkowych stosowane są nanomateriały, które wnikając w pory i mikropęknięcia skały, uszczelniają matrycę łupków, ograniczając wzrost ciśnienia porowego w pobliżu otworu. Jednym z najczęściej wykorzystywanych nanomateriałów jest ditlenek krzemu (krzemionka - $\mathrm{SiO}_{2}$ ). Dostępność tego materiału oraz jego specyficzne właściwości przyczyniły się do jego szerokiego zastosowania. Jest on trwały w wodzie i w podwyższonych temperaturach, a dodatkowo to dobry izolator. Średnica nanocząstek ditlenku krzemu produkowanego w przemyśle najczęściej zawiera się w przedziale od $5 \mathrm{~nm}$ do $100 \mathrm{~nm}$ [4, 9, $18,22]$. Próby zastosowania nanomateriałów w postaci nanokrzemionki nie przyniosły oczekiwanych rezultatów z uwagi na małą stabilność materiału w płuczkach wiertniczych oraz na niedostateczne doszczelnianie przestrzeni porowej skał łupkowych. Ostatnimi laty przedstawiono szereg badań laboratoryjnych potwierdzających zmniejszanie ciśnienia porowego łupków pod wpływem stosowania w płuczkach wiertniczych krzemianów i związków glinu [7, 11, 15, 16, 20].

Kolejnym ze sposobów zwiększenia stabilności formacji łupkowych jest stosowanie w składach płuczek wiertniczych emulsji lateksowych w połączeniu ze związkami glinu. Emulsje lateksowe od wielu lat są z powodzeniem używane w składach zaczynów cementowych. Lateks w zaczynie cementowym służy głównie do kontrolowania filtracji oraz ograniczania migracji gazu. W składach płuczek wiertniczych dodatek lateksu powinien wpływać na zmniejszenie filtracji poprzez wytwarzanie na powierzchni skał łupkowych odkształcalnego uszczelnienia, ograniczającego wzrost ciśnienia porowego skał łupkowych $[1,6,11,13,21]$.

\section{Badania laboratoryjne}

\section{Badania nad doborem lateksów do pluczek wiertniczych}

Lateks to wodna zawiesina polimeru węglowodorowego, występująca naturalnie w niektórych gatunkach drzew lub wytwarzana syntetycznie. Koloidalny roztwór kauczuku naturalnego otrzymywany jest poprzez nacinanie roślin kauczukodajnych i obróbkę soku mlecznego. Natomiast lateks syntetyczny to wodna dyspersja otrzymywana w technologii kopolimeryzacji emulsyjnej kopolimeru butadienowo-styrenowego, polimetakrylanu metylu, kopolimeru polioctanu winylu, kopo- limeru chlorku winylu, polioctanu winylu, polidimetylosiloksanu lub innych $[8,19]$. W zależności od zastosowania lateks może zawierać różne dodatki modyfikujące. Ogólnie uważany jest za system metastabilny. Duża powierzchnia cząsteczek jest termodynamicznie nietrwała i każdy czynnik wpływający na zrównoważenie siły stabilizującej dyspersję polimerową powoduje zmianę kinetyki aglomeracji cząsteczek. Większość dostępnych lateksów przeznaczona jest do produkcji farb. Lateksy te są wrażliwe na wzrost zasolenia i temperaturę. 
W celu doboru odpowiednich lateksów przeprowadzono badania ich odporności na zasolenie i działanie podwyższonej temperatury. Jak wykazały przeprowadzone testy (tablica 1), spośród przebadanych 11 próbek lateksu w 20-proc. roztworze $\mathrm{NaCl}$ najbardziej trwałe okazały się lateksy P, S i lateks 14, w przypadku których nie zauważono koagulacji i rozdziału faz. Mniejszą odpornością na zasolenie wykazały się lateksy 63 i 70, dla których odnotowano dużą ilość wytrąconego osadu.

Tablica 1. Badanie odporności lateksów na zasolenie

\begin{tabular}{|l|c|c|}
\hline Rodzaj lateksu & 20-proc. r-r NaCl & 26-proc. r-r NaCl \\
\hline Lateks 14 & r-r stabilny, brak osadu & brak osadu \\
\cline { 1 - 1 } Lateks 15 & $\begin{array}{r}\text { r-r stabilny, niewielka } \\
\text { ilość osadu }\end{array}$ & \\
\cline { 1 - 1 } Lateks FW & & \multirow{2}{*}{ duża ilość osadu } \\
\cline { 1 - 1 } Lateks 55 & & \\
\cline { 1 - 1 } Lateks 63 & & \\
\cline { 1 - 1 } Lateks 70 & & \\
\cline { 1 - 1 } Lateks 1M & & \multirow{2}{*}{ minimalna osadu ilość } \\
\cline { 1 - 1 } Lateks 035 & brak osadu & \\
\cline { 1 - 1 } Lateks N50 & & \\
\cline { 1 - 1 } Lateks P & & \\
\cline { 1 - 1 } Lateks S & &
\end{tabular}

Spośród przebadanych lateksów w 26-proc. roztworze $\mathrm{NaCl}$ emulsja lateksowa 14 charakteryzowała się najwyższą odpornością na zasolenie. Zwiększenie temperatury do $80^{\circ} \mathrm{C}$ znacznie obniżyło stabilność takiego układu i lateks 14 wydzielił się z roztworu. Badania nad zwiększeniem odporności lateksów na zasolenie i podwyższoną temperaturę prowadzono poprzez włączenie do ich składu środków powierzchniowo czynnych. Do wybranego na podstawie badań wstępnych lateksu 14 dodawano różne rodzaje środków powierzchniowo czynnych. Tak przygotowane mieszaniny lateksu i środków powierzchniowo czynnych wprowadzano w ilości 3\% obj. do 26-proc. roztworu $\mathrm{NaCl}$, mieszano za pomocą mieszadeł mechanicznych i poddawano wygrzewaniu w warunkach statycznych $\mathrm{w}$ temperaturze $80^{\circ} \mathrm{C}$ przez okres 16 godzin. Po ochłodzeniu roztworów do temperatury $20^{\circ} \mathrm{C}$ roztwory przelewano przez sito 100 mesh. Następnie oddzielony z sita osad przemywano wodą, suszono w temperaturze $105^{\circ} \mathrm{C}$ i ważono, określając jego ilość.

Badania nad doborem środków powierzchniowo czynnych do lateksu 14 wykazały, że dodatek środka powierzchniowo czynnego K30 pozwolił na ustabilizowanie układu emulsyjnego. Dobre wyniki uzyskano także przy dodatku 0,3\% GCA (tablica 2). Natomiast największą trwałość układu osiągnięto przy zmieszaniu lateksu 14 ze środkami powierzchniowo czynnymi K30 i DEA w stosunku 9 do 1 . Otrzymaną mieszaninę lateksową nazwano lateksem KW. Zmodyfikowany skład
Tablica 2. Dobór środków powierzchniowo czynnych do lateksu 14

\begin{tabular}{|c|c|c|c|}
\hline \multicolumn{2}{|c|}{$\begin{array}{c}\text { Rodzaj środka } \\
\text { powierzchniowo czynnego } \\
{[\%]}\end{array}$} & \multirow{2}{*}{$\begin{array}{c}\text { 26-proc. r-r } \mathrm{NaCl} \\
+3 \% \text { lateksu } 14 \\
\text { r-r stabilny }\end{array}$} & \multirow{2}{*}{$\begin{array}{l}\text { Ilość osadu } \\
\qquad[\mathrm{g}] \\
\text { brak osadu }\end{array}$} \\
\hline K30 & 0,3 & & \\
\hline K3 & 0,6 & \multirow{3}{*}{ r-r niestabilny } & 0,3 \\
\hline NL6 & 0,3 & & 0,2 \\
\hline K15 & 0,3 & & 0,3 \\
\hline GCA & 0,3 & r-r stabilny & \multirow{14}{*}{ brak osadu } \\
\hline DEA & 0,3 & r-r niestabilny & \\
\hline K30 & 0,4 & \multirow{12}{*}{ r-r stabilny } & \\
\hline DEA & 0,2 & & \\
\hline K30 & 0,2 & & \\
\hline DEA & 0,4 & & \\
\hline K30 & 0,4 & & \\
\hline P600 & 0,2 & & \\
\hline K30 & 0,2 & & \\
\hline P600 & 0,4 & & \\
\hline K30 & 0,2 & & \\
\hline GCA & 0,4 & & \\
\hline K30 & 0,4 & & \\
\hline GCA & 0,2 & & \\
\hline
\end{tabular}

lateksu KW tworzy w środowisku zasolonym $26 \% \mathrm{NaCl}$ stabilne i trwałe układy emulsyjne charakteryzujące się wysoką odpornością na działanie temperatury $80^{\circ} \mathrm{C}$. Opracowany skład lateksu zastosowano w dalszych badaniach, wprowadzając go do płuczki wiertniczej.

\section{Badania laboratoryjne nad doborem zwiazków glinu do pluczek wiertniczych}

Podstawowym składnikiem płuczki lateksowo-glinowej jest lateks, którego główne zadanie stanowi stabilizowanie przewiercanych skał łupkowych poprzez ograniczanie wzrostu ciśnienia powstającego w porach skał łupkowych. Drugim, nie mniej ważnym składnikiem płuczki lateksowo-glinowej jest środek ułatwiający wytrącanie się osadu w porach skał łupkowych. Uważa się, że środek strącający w kontakcie z powierzchnią ściany otworu stanowi bardzo aktywną powierzchnię polarną. Środek strącający dodawany do płuczek w kombinacji z lateksem powinien być stabilny w roztworze, a wytrącać się dopiero w porach skał łupkowych i na ścianach otworu wiertniczego. Odpowiednimi środkami strącającymi mogą być np.: krzemiany, kompleksy glinu i ich mieszaniny. Zalecane są w szczególności środki rozpuszczalne w wodzie i charakteryzujące się $\mathrm{pH}$ powyżej $9[1,11,13,21]$.

Badania nad doborem środka strącającego (tablica 3) wykazały, że spośród przebadanych środków najmniej reaktywny 
Tablica 3. Badania nad doborem rodzaju środka strącającego do płuczki wiertniczej

\begin{tabular}{|c|c|c|c|c|c|c|c|c|c|}
\hline \multirow[t]{2}{*}{$\begin{array}{l}\mathrm{Nr} \\
\text { płuczki }\end{array}$} & \multirow{2}{*}{\multicolumn{2}{|c|}{$\begin{array}{c}\text { Skład płuczki } \\
{[\%]}\end{array}$}} & \multirow{2}{*}{$\begin{array}{c}\text { Gęstość } \\
{\left[\mathrm{kg} / \mathrm{m}^{3}\right]} \\
\rho\end{array}$} & \multicolumn{2}{|c|}{$\begin{array}{l}\text { Lepkość } \\
{[\mathrm{mPa} \cdot \mathrm{s}]}\end{array}$} & \multirow{2}{*}{$\begin{array}{c}\begin{array}{c}\text { Granica } \\
\text { płynięcia } \\
{[\mathrm{Pa}]}\end{array} \\
\tau_{y}\end{array}$} & \multirow{2}{*}{$\begin{array}{c}\text { Wytrzymałość } \\
\text { strukturalna } \\
{[\mathrm{Pa}]} \\
\mathrm{I} / \mathrm{II}\end{array}$} & \multirow[t]{2}{*}{$\begin{array}{l}\text { Filtracja } \\
\qquad\left[\mathrm{cm}^{3}\right]\end{array}$} & \multirow[t]{2}{*}{$\mathrm{pH}$} \\
\hline & & & & $\eta_{p l}$ & $\eta_{s}$ & & & & \\
\hline 1 & Potasowo-polimerowa & & 1080 & 33 & 51,0 & 17,2 & $2,9 / 3,8$ & 6,0 & 9,6 \\
\hline 2 & $\begin{array}{l}\text { Płuczka } 1 \\
+\mathrm{NaAlO}_{2}\end{array}$ & 0,6 & 1080 & 33 & 51,0 & 17,2 & $2,4 / 3,3$ & 4,4 & 11,5 \\
\hline 3 & $\begin{array}{l}\text { Płuczka } 1 \\
+ \text { SAX } 18\end{array}$ & 0,6 & 1080 & 30 & 46,0 & 15,3 & $2,4 / 3,3$ & 4,8 & 10,8 \\
\hline 4 & $\begin{array}{l}\text { Płuczka } 1 \\
+\mathrm{AlK}\left(\mathrm{SO}_{4}\right)_{2} \cdot 12 \mathrm{H}_{2} \mathrm{O}\end{array}$ & 0,6 & 1080 & 30 & 47,0 & 16,2 & $2,9 / 3,8$ & 6,4 & 8,7 \\
\hline 5 & $\begin{array}{l}\text { Płuczka } 1 \\
+ \text { szkło sodowe R140 }\end{array}$ & 0,6 & 1080 & 31 & 48,5 & 16,7 & $2,9 / 3,8$ & 5,6 & 10,0 \\
\hline 6 & $\begin{array}{l}\text { Płuczka } 1 \\
+\mathrm{NH}_{4} \mathrm{Al}\left(\mathrm{SO}_{4}\right)_{2} \cdot 12 \mathrm{H}_{2} \mathrm{O}\end{array}$ & 0,6 & 1080 & 30 & 45,0 & 14,3 & $2,9 / 3,8$ & 8,0 & 7,9 \\
\hline 7 & $\begin{array}{l}\text { Płuczka } 1 \\
+ \text { PAX } 16\end{array}$ & 0,6 & 1075 & 28 & 43,0 & 14,3 & $2,9 / 3,8$ & 8,4 & 7,8 \\
\hline
\end{tabular}

w stosunku do płuczki wiertniczej okazał się glinian sodu. Dodany do płuczki w ilości 0,6\% spowodował wzrost wartości pH płuczki z 9,6 do 11,5 oraz wpłynął na ograniczenie wartości filtracji z $6 \mathrm{~cm}^{3} / 30 \mathrm{~min}$ do $4,4 \mathrm{~cm}^{3} / 30 \mathrm{~min}$. Lepkość plastyczna płuczki nie zmieniła się i wynosiła $33 \mathrm{mPa} \cdot \mathrm{s}$ (tablica 3). Drugim rodzajem środka strącającego, który może być zastosowany do płuczki lateksowo-glinowej, może być szkło sodowe R140. Szkło sodowe jako środek strącający dodany do płuczki w ilości 0,6\% wpływa na obniżenie lepkości plastycznej płuczki z $33 \mathrm{mPa} \cdot \mathrm{s}$ do $31 \mathrm{mPa} \cdot \mathrm{s}$, a granicy płynięcia z 17,2 Pa do 16,7 Pa. Wartość pH płuczki wzrosła z 9,6 do 10,0, a filtracja obniżyła się z $6 \mathrm{~cm}^{3} / 30 \mathrm{~min}$ do $5,6 \mathrm{~cm}^{3} / 30 \mathrm{~min}$ (tablica 3). Pozostałe przebadane środki wykazują zbyt reaktywne działanie w stosunku do płuczki wiertniczej, wpływając na zmianę parametrów reologiczno-strukturalnych płuczki, wzrost wartości filtracji oraz obniżenie wartości pH (tablica 3).

W prowadzonych testach wybrany środek strącający - glinian sodu próbowano łączyć z innymi środkami w celu wytworzenia stabilnych kompleksów glinowych. Poprzez połączenie związków glinu z kwasami organicznymi uzyskano kompleks glinowy B, który wykazywał dużą zgodność z lateksem KW i polimerami stosowanymi w składzie płuczki wiertniczej.

\section{Badania wplywu opracowanych środków na właściwości pluczek wiertniczych}

Sporządzone systemy płuczkowe zawierające lateks KW i kompleks glinowy B poddane zostały badaniom w celu określenia zmian ich parametrów reologicznych, filtracji, właściwości inhibicyjnych oraz ich wpływu na właściwości skał łupkowych. Badania opracowanych płuczek prowadzono równolegle z płuczką potasowo-polimerową oraz solno-polimerową.
Wykonane w temperaturze otoczenia badania laboratoryjne płuczki zawierającej w swoim składzie połączenie lateksu KW z kompleksem glinowym B wykazały, że jej właściwości nie różnią się znacząco od właściwości płuczki potasowo-polimerowej. Lepkość plastyczna płuczek lateksowo-glinowych wynosiła od $38 \mathrm{mPa} \cdot \mathrm{s}$ do $41 \mathrm{mPa} \cdot \mathrm{s}$, a granica płynięcia 21,5 Pa (tablica 4). Stwierdzono jedynie, że zastosowany w składzie płuczki lateks KW i kompleks glinowy B spowodował obniżenie filtracji w porównaniu z płuczką wyjściową oraz wzrost wartości pH do 10,7 (tablica 4).

Natomiast w płuczce solno-polimerowej dodatek lateksu KW i kompleksu glinowego B wpłynął na zwiększenie lepkości plastycznej płuczki o $4 \mathrm{mPa} \cdot \mathrm{s}$, wzrost wartości $\mathrm{pH}$ do 10,3 i obniżenie filtracji płuczki z $7,2 \mathrm{~cm}^{3} / 30 \mathrm{~min}$ do $4 \mathrm{~cm}^{3} / 30 \mathrm{~min}$. W przypadku płuczki lateksowo-glinowej z dodatkiem 3\% inhibitora skał ilasto-łupkowych lepkość plastyczna wzrosła do $48 \mathrm{mPa} \cdot \mathrm{s}$, a granica płynięcia do $23 \mathrm{~Pa}$. Zauważalne jest także obniżenie filtracji płuczki do $4 \mathrm{~cm}^{3} / 30 \mathrm{~min}$.

Mechanizm zmniejszania filtracji płuczek lateksowo-glinowych polega głównie na tworzeniu podczas przewiercania formacji łupkowych odkształcalnego uszczelnienia, które częściowo wpływa na zmniejszenie porowatości skały łupkowej, blokując dostęp filtratu płuczkowego do matrycy skalnej. W związku z powyższym sprawdzono także zdolność zastosowanych środków do zmniejszania filtracji płuczek wiertniczych i uszczelniania przestrzeni porowej skał łupkowych. Filtrację płuczek badano na prasie filtracyjnej HPHT w temperaturze $50^{\circ} \mathrm{C}$ i $100^{\circ} \mathrm{C}$ przy ciśnieniu różnicowym $0,7 \mathrm{MPa}$.

Filtracja płuczki potasowo-polimerowej (A) w temperaturze $50^{\circ} \mathrm{C}$ wynosiła $7,2 \mathrm{~cm}^{3} / 30 \mathrm{~min}$, natomiast $\mathrm{w}$ temperaturze $100^{\circ} \mathrm{C}$ wzrosła do $7,8 \mathrm{~cm}^{3} / 30$ min (rysunek 1). 
Tablica 4. Wpływ dodatku lateksu KW i kompleksu glinowego B na właściwości płuczki potasowo-polimerowej i solno-polimerowej

\begin{tabular}{|c|c|c|c|c|c|c|c|c|c|}
\hline \multirow{2}{*}{$\begin{array}{c}\mathrm{Nr} \\
\text { płuczki }\end{array}$} & \multirow{2}{*}{\multicolumn{2}{|c|}{$\begin{array}{c}\text { Skład płuczki } \\
{[\%]}\end{array}$}} & \multirow{2}{*}{$\begin{array}{c}\text { Gęstość } \\
{\left[\mathrm{kg} / \mathrm{m}^{3}\right]} \\
\rho\end{array}$} & \multicolumn{2}{|c|}{$\begin{array}{l}\text { Lepkość } \\
{[\mathrm{mPa} \cdot \mathrm{s}]}\end{array}$} & \multirow{2}{*}{$\begin{array}{c}\begin{array}{c}\text { Granica } \\
\text { płynięcia } \\
{[\mathrm{Pa}]}\end{array} \\
\tau_{y}\end{array}$} & \multirow{2}{*}{$\begin{array}{l}\text { Wytrzymałość } \\
\text { strukturalna } \\
{[\mathrm{Pa}]} \\
\mathrm{I} / \mathrm{II}\end{array}$} & \multirow{2}{*}{$\begin{array}{c}\text { Filtracja } \\
\qquad\left[\mathrm{cm}^{3}\right]\end{array}$} & \multirow[t]{2}{*}{$\mathrm{pH}$} \\
\hline & & & & $\eta_{p l}$ & $\eta_{s}$ & & & & \\
\hline 1 & Potasowo-polimerowa & & 1080 & 38 & 60,5 & 21,5 & $3,3 / 4,8$ & 6,8 & 9,4 \\
\hline 2 & $\begin{array}{l}\text { Płuczka } 1 \\
\text { + lateks KW } \\
\text { + kompleks glinowy B }\end{array}$ & $\begin{array}{l}3,0 \\
0,6\end{array}$ & 1080 & 38 & 61,0 & 22,0 & $3,3 / 4,8$ & 5,6 & 10,7 \\
\hline 3 & $\begin{array}{l}\text { Płuczka } 1 \\
\text { + DAMP } \\
\text { + lateks KW } \\
\text { + kompleks glinowy B }\end{array}$ & $\begin{array}{l}3,0 \\
3,0 \\
0,6\end{array}$ & 1080 & 41 & 63,5 & 21,5 & $3,3 / 4,8$ & 5,2 & 9,5 \\
\hline 4 & Solno-polimerowa & & 1190 & 40 & 63,0 & 22,0 & $2,9 / 4,3$ & 7,2 & 9,1 \\
\hline 5 & $\begin{array}{l}\text { Płuczka } 4 \\
\text { + lateks KW } \\
\text { + kompleks glinowy B }\end{array}$ & $\begin{array}{l}3,0 \\
0,6\end{array}$ & 1190 & 44 & 67,5 & 22,5 & $3,3 / 4,8$ & 4,0 & 10,3 \\
\hline 6 & $\begin{array}{l}\text { Płuczka } 4 \\
\text { + DAMP } \\
\text { + lateks KW } \\
\text { + kompleks glinowy B }\end{array}$ & $\begin{array}{l}3,0 \\
3,0 \\
0,6\end{array}$ & 1190 & 48 & 72,0 & 23,0 & $3,3 / 4,8$ & 4,0 & 9,4 \\
\hline
\end{tabular}

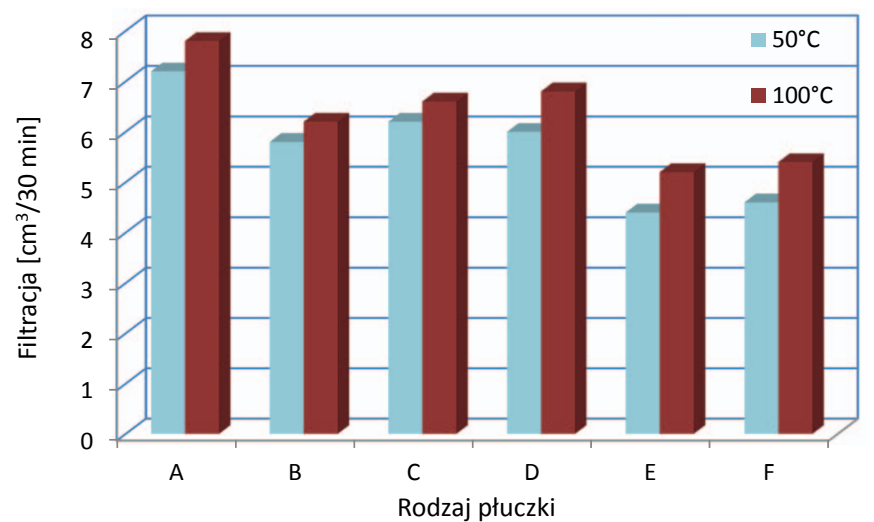

Rys. 1. Wartości filtracji płuczek w temperaturze $50^{\circ} \mathrm{C}$ i $100^{\circ} \mathrm{C}$ przy ciśnieniu różnicowym $0,7 \mathrm{MPa}$

Zastosowanie w składzie płuczki potasowo-polimerowej lateksu KW i kompleksu glinowego B wpłynęło na niewielkie obniżenie filtracji. W temperaturze $50^{\circ} \mathrm{C}$ filtracja płuczki B $\mathrm{w}$ porównaniu $\mathrm{z}$ płuczką potasowo-polimerową obniżyła się o $1,4 \mathrm{~cm}^{3} / 30 \mathrm{~min}$, a w temperaturze $100^{\circ} \mathrm{C} \mathrm{o} 1,6 \mathrm{~cm}^{3} / 30 \mathrm{~min}$ (rysunek 1). Filtracja płuczki solno-polimerowej (D) w temperaturze $50^{\circ} \mathrm{C}$ wynosiła $6,2 \mathrm{~cm}^{3} / 30 \mathrm{~min}$, a w temperaturze $100^{\circ} \mathrm{C}: 6,8 \mathrm{~cm}^{3} / 30 \mathrm{~min}$. Wprowadzenie do płuczki solno-polimerowej lateksu KW i kompleksu glinowego B także wpłynęło na obniżenie wartości filtracji. Najniższą wartość filtracji uzyskano dla płuczki lateksowo-glinowej zasolonej 20\% $\mathrm{NaCl}(\mathrm{E})-\mathrm{w}$ temperaturze $50^{\circ} \mathrm{C}$ wyniosła ona $4,4 \mathrm{~cm}^{3} / 30 \mathrm{~min}$, a w temperaturze $100^{\circ} \mathrm{C}$ wzrosła do $5,4 \mathrm{~cm}^{3} / 30$ min (rysunek 1).

Badania filtracji płuczek w warunkach statycznych wykazały, że zastosowane w składach płuczek wiertniczych opra-

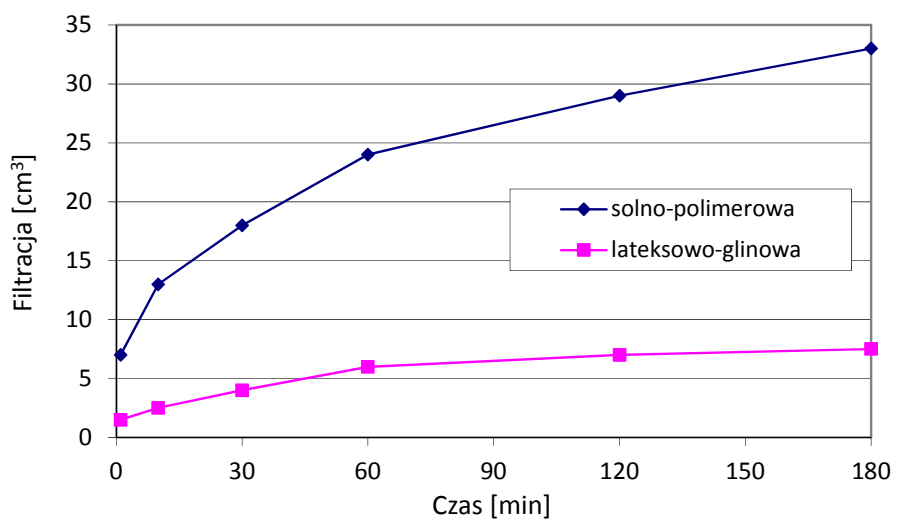

Rys. 2. Wartości filtracji płuczek w temperaturze $60^{\circ} \mathrm{C}$ przy ciśnieniu różnicowym $3,5 \mathrm{MPa}$

cowane stabilizatory skał łupkowych (lateks KW i kompleks glinowy B) wpływają na zmniejszenie filtracji tych płuczek.

Skuteczność uszczelniania przestrzeni porowej poprzez opracowane płuczki wiertnicze określono także za pomocą badań filtracji płuczek w warunkach dynamicznych. Filtrację prowadzono na dysku ceramicznym o wielkości porów $10 \mu \mathrm{m}$ i przepuszczalności $775 \mathrm{mD}$, przy ciśnieniu różnicowym $3,5 \mathrm{MPa}$ i temperaturze $60^{\circ} \mathrm{C}$. Wyniki badań przedstawiono na rysunku 2. Badania filtracji płuczek wykonywano przez 180 minut, mierząc jej wartości w określonych interwałach czasowych po 1, 10, 30, 60, 120 i $180 \mathrm{~min}$.

Filtracja płuczki solno-polimerowej po 1 minucie wynosiła około $7 \mathrm{~cm}^{3}$, po 10 minutach wzrosła do $13 \mathrm{~cm}^{3}$, a całkowita filtracja po czasie 180 minut wynosiła $34 \mathrm{~cm}^{3}$. Płuczka lateksowo-glinowa charakteryzowała się w warunkach 
dynamicznych znacznie niższą filtracją. Początkowa filtracja, zmierzona po 1 minucie, wynosiła $1,5 \mathrm{~cm}^{3}$, po $10 \mathrm{mi}-$ nutach nieznacznie wzrosła do $2,5 \mathrm{~cm}^{3}$, a całkowita filtracja płuczki po 180 minutach wynosiła $7,5 \mathrm{~cm}^{3}$ (rysunek 2). Z przebiegu krzywych można również zauważyć, że filtracja płuczki solno-polimerowej gwałtownie rośnie w początkowym okresie pomiaru, później ulega niewielkiemu obniżeniu, a następnie utrzymuje się na podobnym poziomie przez cały czas pomiaru.

Zdolność uszczelniania dysku ceramicznego przez płuczkę lateksowo-glinową jest znacznie większa. Średnie wartości filtracji w poszczególnych interwałach czasowych ulegają zmniejszeniu, by po 120 minutach ustabilizować się na stałym poziomie i w końcowym etapie ograniczyć filtrację prawie do zera. Dla porównania filtracja płuczki solno-polimerowej wzrasta przez cały czas pomiaru (rysunek 2).

Na podstawie przeprowadzonych badań filtracji płuczek stwierdzono, że obieg płuczki podczas badania jest ważnym elementem mechanizmu uszczelniania przestrzeni porowej przez lateks. Wytrącony osad może skutecznie uszczelnić pory i zmniejszać straty płuczki wiertniczej w przepuszczalne formacje łupkowe o niskiej przepuszczalności, gdzie materiały (LCM) nie są skuteczne.

\section{Badania wplywu opracowanej pluczki lateksowo-glinowej na wlaściwości} skat tupkowych

Wpływ oddziaływania opracowanych płuczek wiertniczych na właściwości skał łupkowych określono poprzez badania pęcznienia skał ilasto-łupkowych, badania dyspersji skał oraz poprzez badania ciśnienia powstającego $\mathrm{w}$ porach skał łupkowych w wyniku mikroprzepływu filtratu płuczkowego.

\section{Badania dyspersji}

Badania określające właściwości inhibicyjne opracowanych płuczek przeprowadzono na próbkach skał ilasto-łupkowych reprezentowanych przez tupek mioceński. Badania wykonano dla płuczek zawierających 3\% lateksu KW oraz dla płuczek zawierających lateks KW w połączeniu z kompleksem glinowym B.

Przeprowadzona analiza dyspersyjna opracowanych płuczek wykazała, że w stosunku do płuczki potasowo-polimerowej dodatek opracowanych stabilizatorów skał łupkowych wpływa na zwiększenie jej właściwości inhibicyjnych. Wartości odzysku łupku mioceńskiego dyspergowanego w płuczce $\mathrm{z}$ dodatkiem 3\% lateksu KW i 0,6\% kompleksu glinowego B wynosiły około $98 \%$, natomiast po powtórnym dyspergowa- niu go w wodzie $\left(P_{2}\right)$ - około $58 \%$ (rysunek 3 ). Dla porównania ilość łupku mioceńskiego odzyskana po dyspergowaniu go w płuczce potasowo-polimerowej wynosiła $88 \%$, a po dyspergowaniu go w wodzie $\left(P_{2}\right)$ - około $26 \%$. W płuczce $\mathrm{z}$ dodatkiem 3\% inhibitora DAMP w połączeniu z lateksem KW i kompleksem glinowym B łupek nie dyspergował, a po powtórnym dyspergowaniu go w wodzie tylko $10 \%$ łupku uległo dezintegracji (rysunek 3). Dodatek stabilizatorów skał ilasto-łupkowych (lateks KW, kompleks glinowy B) do płuczki solno-polimerowej także wpływa na zwiększenie właściwości inhibicyjnych płuczki w stosunku do łupku mioceńskiego. Ilość odzysku łupku po dyspergowaniu go w płuczce lateksowo-glinowej wzrasta w porównaniu z płuczką solno-polimerową o około $10 \%$. Uzyskano natomiast wzrost wartości odzysku łupku po powtórnym dyspergowaniu go w wodzie o około 30\% (rysunek 3). Synergizm działania stabilizatorów skał ilasto-łupkowych z inhibitorem aminowym DAMP uwidacznia się także w środowisku płuczki solno-polimerowej. Wartości odzysku łupku po dyspergowaniu go w płuczce wynoszą $98 \%\left(P_{1}\right)$, a po powtórnym oddziaływaniu wody - około $88 \%\left(P_{2}\right)$.

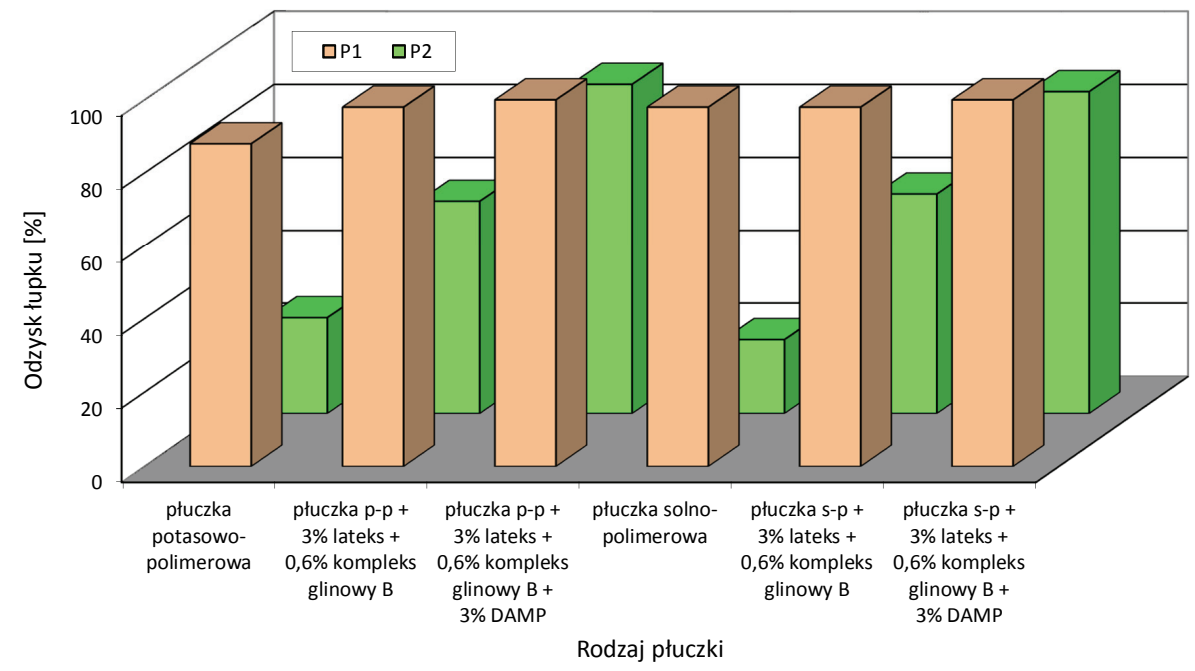

Rys. 3. Właściwości inhibicyjne opracowanych płuczek lateksowo-glinowych

\section{Badanie pęcznienia tupków}

Przedstawione badania pęcznienia łupku mioceńskiego wykonane zostały w celu określenia zdolności ograniczania przyrostu jego objętości przez opracowane płuczki lateksowo-glinowe. Do badań laboratoryjnych wytypowano dwa rodzaje płuczek: płuczkę lateksowo-glinową zawierającą $7 \%$ inhibitora jonowego $\mathrm{KCl}$ oraz płuczkę lateksowo-glinową zasoloną zawierającą $7 \% \mathrm{KCl}$ i $20 \% \mathrm{NaCl}$. Dla porównania przeprowadzono dodatkowo badania dla płuczki potasowo-polimerowej i płuczki solno-polimerowej. Wyniki badań pęcznienia skał ilasto-łupkowych przedstawiono graficznie na rysunku 4. 


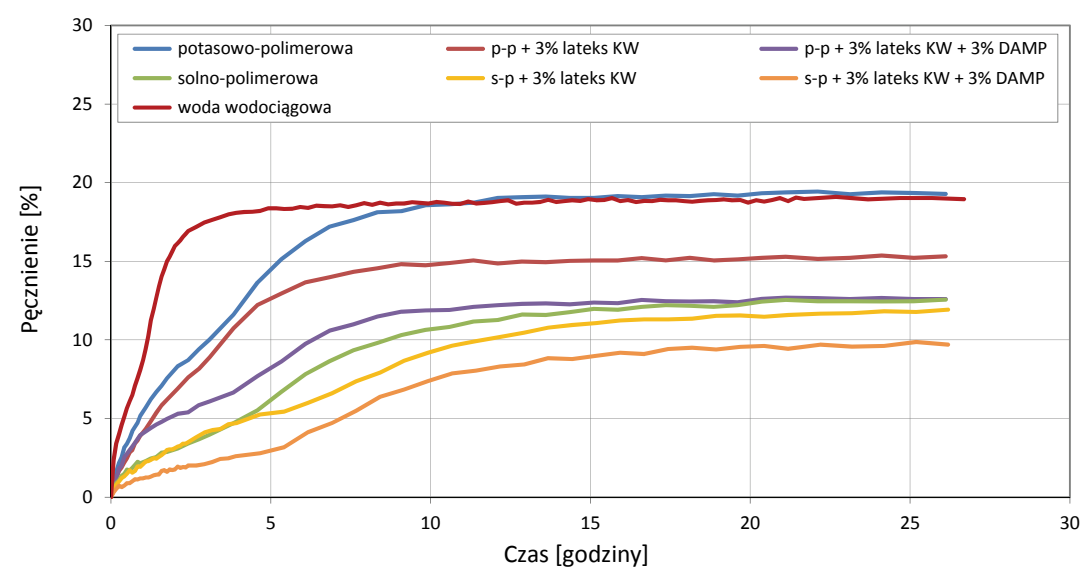

Rys. 4. Pęcznienie łupku mioceńskiego w zależności od rodzaju zastosowanej płuczki wiertniczej sto-łupkowych (3\% DAMP), dla której spęcznienie wynosiło 9,79\% (rysunek 4). Zastosowanie w składzie płuczek wiertniczych odpowiednich stabilizatorów i inhibitorów hydratacji skał ilasto-łupkowych jest w stanie ograniczyć pęcznienie łupku mioceńskiego do poziomu poniżej $10 \%$.

\section{Badania ciśnienia porowego PPT skat hupkowych}

Badania ciśnienia porowego PPT (pore pressure transmission) przeprowadzono na próbce łupku eoceńskiego charakteryzującego się porowatością 28,4\% i przepuszczalnością 0,076 mD przy średniej średnicy porów $618 \mathrm{~A}$. Gęstość badanej próbki wynosiła $1,713 \mathrm{~g} / \mathrm{cm}^{3}$, a całkowita

Wysuszony łupek mioceński w wyniku działania wody już po upływie 2 godz. zwiększył swoją objętość o około 16\%, a po upływie 25 godz. jego pęcznienie wzrosło do 19\% (rysunek 4). Pęcznienie próbek łupku mioceńskiego w środowisku płuczek wiertniczych przebiega znacznie wolniej. W płuczce potasowo-polimerowej próbka łupku mioceńskiego po upływie 5 godz. zwiększyła swoją objętość o 15\%, a całkowite spęcznienie jej wynosiło 19,2\% (rysunek 4). Zastosowanie w składzie płuczki potasowo-polimerowej 3\% lateksu KW i 0,6\% kompleksu glinowego B wpłynęło na znaczne ograniczenie tempa pęcznienia próbki łupku mioceńskiego. Próbka skały ilasto-łupkowej w środowisku płuczki lateksowo-glinowej po upływie 10 godz. zwiększyła swoją objętość o 15\%. Dalsze prowadzenie testu do 25 godz. nie spowodowało zwiększenia spęcznienia próbki i ustabilizowało się ono na poziomie 15,2\% (rysunek 4). Połączenie ze sobą w składzie płuczki lateksu KW, kompleksu glinowego B oraz inhibitora hydratacji skał ilasto-łupkowych spowodowało, że próbka łupku mioceńskiego w środowisku płuczki znacznie ograniczyła swe pęcznienie w porównaniu z płuczką potasowo-polimerową. Objętość próbki łupku mioceńskiego wzrosła po 25 godz. testu o 12,51\% (rysunek 4). Pęcznienie próbek łupku mioceńskiego w płuczkach zasolonych $20 \% \mathrm{NaCl}$ przebiega znacznie wolniej niż w płuczkach zawierających 7\% KCl. Spęcznienie próbki łupku mioceńskiego w wyniku oddziaływania płuczki solno-polimerowej wynosiło 12,25\% (rysunek 4). Efektywność działania zastosowanych stabilizatorów skał łupkowych (3\% lateksu KW i 0,6\% kompleksu glinowego B) zauważalna jest również w środowisku płuczki solno-polimerowej. W wyniku działania użytych środków spęcznienie próbki skały łupkowej wynosiło 11,94\% (rysunek 4). Natomiast w najmniejszym stopniu swoją objętość zwiększyła próbka łupku mioceńskiego w wyniku oddziaływania płuczki zawierającej stabilizatory skał łupkowych (3\% lateksu KW i 0,6\% kompleksu glinowego B) i z dodatkiem inhibitora hydratacji skał ila- powierzchnia porów $10,757 \mathrm{~m}^{2} / \mathrm{g}$. Przepływ badanej cieczy przez łupek eoceński powoduje wzrost ciśnienia, które jest rejestrowane za pomocą miernika ciśnienia i wykreślane w zależności od czasu pomiaru. Wyniki przenikania ciśnienia porowego łupku eoceńskiego dla płuczek wiertniczych przedstawiono na rysunku 5.

Na próbkę łupku eoceńskiego oddziaływano płuczką solno-polimerową przy ciśnieniu 1,8 MPa. Była ona cyrkulowana przez 64 godz. W wyniku 7-godz. oddziaływania płuczki na próbkę ciśnienie porowe formacji łupkowej wzrosło do 0,22 MPa. Po 24 godz. przenikania płuczki solno-polimerowej ciśnienie wzrosło do 0,3 MPa, a po 40 godz. do 0,37 MPa. Końcowe ciśnienie porowe łupku zmierzone po 64 godz. wynosiło $0,5 \mathrm{MPa}$.

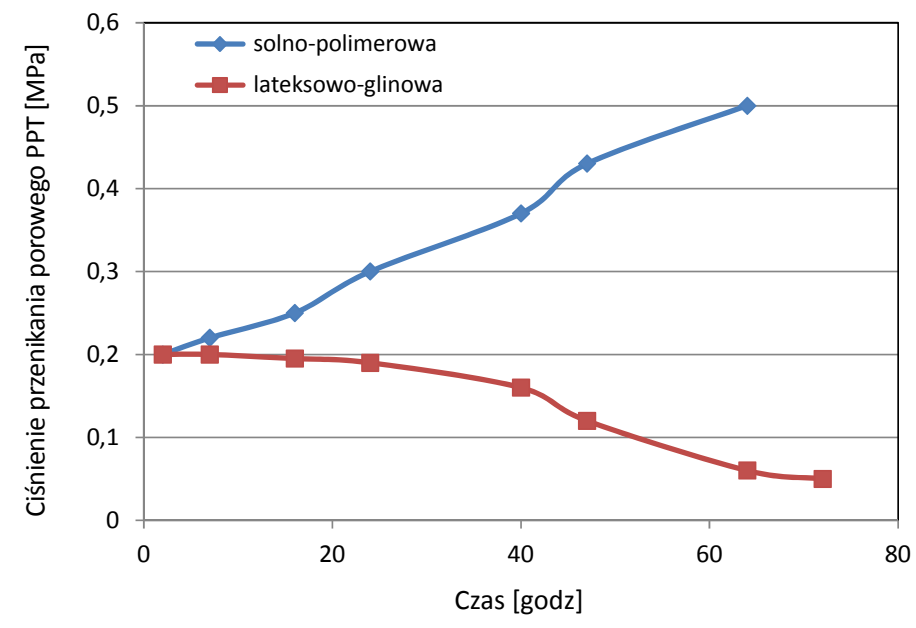

Rys. 5. Wartości ciśnienia porowego łupku eoceńskiego dla płuczki solno-polimerowej i lateksowo-glinowej

W czasie oddziaływania płuczki solno-polimerowej na powierzchni łupku tworzy się osad, przez który do przestrzeni porowej w dalszym ciągu przenika filtrat płuczkowy. Uzyskane wyniki ciśnienia porowego dla łupku eoceńskiego mogą świadczyć 
o tym, że zastosowane materiały w płuczce solno-polimerowej tworzące osad płuczkowy są zbyt dużych rozmiarów, by skutecznie uszczelnić przestrzeń porową skały łupkowej i ograniczyć wnikanie filtratu do matrycy skalnej.

Przeprowadzone badania dla płuczki lateksowo-glinowej wykazały synergistyczne działanie środków wykorzystanych do stabilizacji skał łupkowych (lateks KW, kompleks glinowy B), które spowodowały znaczne ograniczenie wzrostu ciśnienia porowego.

Po 7 godzinach ciągłego oddziaływania płuczki lateksowo-glinowej ciśnienie porowe nie wzrosło i wynosiło 0,2 MPa. W wyniku dalszego 24-godz. oddziaływania płuczki odnotowano niewielki wzrost ciśnienia porowego do 0,22 $\mathrm{MPa}$. W następnych godzinach testu ciśnienie porowe ulegało stopniowemu obniżeniu, by po 40 godz. ciągłego oddziaływania płuczki spaść do 0,16 MPa, a po 47 godz. do 0,12 MPa. Dalsze oddziaływanie płuczki przy ciśnieniu $1,8 \mathrm{MPa}$ nie spowodowało wzrostu ciśnienia porowego. Płuczka lateksowo-glinowa stworzyła stabilne uszczelnienie, które ograniczyło przepływ filtratu płuczkowego przez łupek eoceński. Po 72 godz. testu odnotowano spadek ciśnienia porowego skały łupkowej do 0,05 MPa.

Przeprowadzone badania wykazały, że lateks KW zawarty w filtracie płuczkowym wnika w pory skały łupkowej i gromadzi się w porach i mikroporach skał łupkowych, tworząc elastyczne uszczelnienie. W filtracie płuczkowym występują także w postaci rozpuszczonej związki glinu, które w wyniku kontaktu z solanką złożową wytrącają się w porach skały, tworząc osad glinowy, który doszczelnia przestrzeń porową skały, ograniczając tym samym przepływ filtratu płuczkowego.

\section{Podsumowanie}

1. Wykonane badania laboratoryjne pozwoliły na sformułowanie składu lateksu, który może być stosowany w składach płuczek wiertniczych jako stabilizator skał łupkowych. Opracowany skład lateksu stanowi wodna dyspersja kopolimeru butadienowo-styrenowego stabilizowanego za pomocą odpowiednio dobranych środków powierzchniowo czynnych. Zmodyfikowany lateks KW charakteryzuje się zwiększoną odpornością na zasolenie $\mathrm{NaCl}$ i działanie podwyższonej temperatury. Z uwagi na swoje właściwości może być stosowany zarówno w składach płuczek słodkowodnych zawierających od 5\% do $7 \% \mathrm{KCl}$, jak też w płuczkach wykorzystywanych do przewiercania warstw solnych.

2. Na podstawie badań wpływu lateksu na właściwości płuczki wiertniczej i właściwości dyspersyjnych skał łupkowych ustalono, że optymalne ilości lateksu KW dodawanego do płuczek wiertniczych do przewiercania formacji łupkowych powinny wynosić od 3\% do 5\% w stosunku do całkowitej objętości płuczki.

3. Uwzględniając badania nad ograniczeniem filtracji płuczek wiertniczych, opracowano skład kompleksu glinowego B, który w środowisku płuczki jest stabilny, nato- miast przy kontakcie z solanką złożową o niskim $\mathrm{pH}$ wytrąca się z roztworu, tworząc osad. Opracowany kompleks glinowy B wykazuje dużą zgodność z lateksem KW i polimerami stosowanymi w składzie płuczki wiertniczej.

4. W wyniku przeprowadzonych badań laboratoryjnych opracowano nowy rodzaj płuczki wiertniczej zawierającej w swoim składzie stabilizatory skał łupkowych (lateks KW i kompleks glinowy B) zdolnej do tworzenia na przewiercanych niestabilnych i sypliwych formacjach łupkowych szczelnego i odkształcalnego osadu filtracyjnego, przeciwdziałającego wnikaniu filtratu płuczkowego i ograniczającego wzrost ciśnienia porowego przewiercanej formacji skalnej.

5. Opracowana płuczka do przewiercania formacji łupkowych charakteryzuje się dobrymi właściwościami inhibicyjnymi w stosunku do skał ilasto-łupkowych - wartości odzysku łupku mioceńskiego wynoszą około $98 \div 100 \%$. W bardzo dobrym stopniu zabezpiecza ona również skały ilasto-łupkowe przed działaniem hydratacji osmotycznej. Świadczą o tym wartości dezintegracji łupku mioceńskiego dyspergowanego w wodzie po wstępnym oddziaływaniu płuczki $P_{2}=86 \div 90 \%$.

Prosimy cytować jako: Nafta-Gaz 2018, nr 7, s. 526-534, DOI: 10.18668/NG.2018.07.06

Artykuł nadesłano do Redakcji 18.04.2018 r. Zatwierdzono do druku 12.06.2018 r.

Artykuł powstał na podstawie pracy statutowej pt. Płuczki lateksowo-glinowe do przewiercania niestabilnych formacji łupkowych - praca INiG - PIB na zlecenie MNiSW; nr zlec. 0059/KW/17, nr archiwalny: DK-4100-46/17.

\section{Literatura}

[1] Arambulo S., Colque P., Ahmed M.: Case studies validate the effectiveness of aluminum-based HPWBM in stabilizing micro-fractured shale formations: Field experience in the Peruvian Amazon. SPE Annual Technical Conference and Exhibi- tion, 28-30.09.2015, Houston, Texas, USA, SPE-174854-MS, s. 1-14, DOI: 10.2118/174854-MS.

[2] Chao Liu, Hoang S.K., Tran M.H., Abousleiman Y.N., Ewy R.T.: Poroelastic dual-porosity dual-permeability simulation of pressure 
transmission test on chemically active shale. Journal of Engineering Mechanics 2017, vol. 143, nr 6, DOI: 10.1061/(ASCE) EM.1943-7889.0001210.

[3] Chao M., Lin Z., Yuansen S., Lun L.: Anti-collapse polyamine aluminum drilling fluid system and its application in strong water-sensitive shale formation. EJGE 2014, vol. 19, s. 2691-2704.

[4] Dębińska E.: Niekonwencjonalne zaczyny cementowe z dodatkiem nanokrzemionki. Nafta-Gaz 2015, nr 5, s. 290-300.

[5] Dye B., Clapper D., Hansen N., Leaper R., Shoults L., Otto M., Xiang T., Gusler B.: Design considerations for high performance water-based muds. AADE 2004 Drilling Fluids Conference, 6-7.04.2004, Houston, Texas, AADE-04-DF-HO-14, s. $1-14$.

[6] Ewy R.T., Morton E.K.: Wellbore-Stability Performance of Water-Based Mud Additives. SPE Drilling \& Completion 2009 , vol. 24, nr 3, s. 390-339.

[7] Fritz B., Jarrett M.: Potassium silicate-treated water-based fluid: An effective barrier to instability in the Fayetteville shale. IADC/SPE Drilling Conference and Exhibition, 6-8.03.2012, San Diego, California, USA, IADC/SPE 151491, s. 1-6, DOI: 10.2118/151491-MS

[8] Junyi Liu, Zhengsong Qiu, Wei'an Huang, Dingding Song, Dan Bao: Preparation and characterization of latex particles as potential physical shale stabilizer in water-based drilling fluids, scientific. World Journal 2014, s. 1-8, ID 895678.

[9] Moroni L.P., Vickers S., Gray C., Davidson M.: Good things come in little packages: Nanotechnology for reduction in pore pressure transmission. SPE Annual Technical Conference and Exhibition, 27-29.10.2014, Amsterdam, SPE-170687-MS s. 1-8, DOI.10.2118/170687-MS

10] Prahlad Kumar Yadav, Syed Shujath Ali, Najeeb Ahmed Al Tawat, Ali Abdullah Al Dhamen, Guodong Jin: Effect of drilling fluid on rock mechanical properties at near-drilling conditions. An implication of fluid design on wellbore stability. Offshore Technology Conference Asia, 22-25.03.2016, Kuala Lumpur, Malaysia, s. 1-9, DOI: 10.4043/26460-MS.

[11] Ramirez M.A., Benaissa S., Ragnes G., Almaraz A.: Aluminum-based HPWBM successfully replaces oil-based mud to drill exploratory well in the Magellan Strait, Argentina. SPE/IADC Middle East Drilling and Technology Conference, 22-24.10.2007, Cairo, Egypt, SPE/IADC 108213, s. 1-11, DOI: 10.2118/108213-MS.

[12] Ramirez M.A., Capacho C., Osorio J., Kenny P.: Replacing potassium with aluminum complex overcomes wellbore stability problems in kaolinitic shales in South America. AADE 2004 Drilling Fluids Conference, 6-7.04.2004, Houston, Texas, AADE-04-DF-HO-17, s. 1-12.

[13] Ramirez M.A., Sanchez G., Sarmiento O.E.P., Santamaria J., Luna E.: Aluminum-based HPWBM successfully replaces oilbase mud to drill exploratory wells in an environmental sensitive area. SPE Latin American and Caribbean Petroleum Engineering Conference, 20-23.06.2005, Rio de Janeiro, Brazil, SPE 94437, s. 1-12, DOI: 10.2118/94437-MS.
[14] Rea A.B., Nagatani R., Davis E.S., Carlton T., Coragliotti A., Firliet B., Tran S.: A novel system for controlling pore pressure transmission, inhibition, stabilization and targeted lubrication in water-sensitive shales: Proof-of-concept and initial field results. SPE/IADC Middle East Drilling Technology Conference and Exhibition, 26-28.01.2016, Abu Dhabi, UAE, SPE/ IADC-178215-MS, s. 1-15, DOI: 10.2118/178215-MS.

[15] Stowe C., Halliday W., Xiang T., Clapper D., Morton K., Hartman S.: Laboratory pore pressure transmission testing of shale. AADE 2001 National Drilling Conference, ,Drilling Technology - The Next 100 years", 27-29.03.2001, Houston, Texas, AADE 01-NC-HO-44, s. 1-10.

[16] Tare Uday A., Mody Fersheed K., Mese Ali I.: Understanding chemical-potential-related transient pore-pressure response to improve real-time borehole (in) stability predictions. SPE/ Petroleum Society of CIM 65514, 2005, s. 1-14.

[17] Vickers S., Cowie M., Burgess M., Anderson D.: The application of specifically formulated bridging materials to successfully reduce pore pressure transmission to enable depleted fractured reservoirs to be drilled and produced without incurring formation damage. European Formation Damage Conference, 30.05- 1.06.2007, Scheveningen, The Netherlands, SPE 107753, s. 1-6, DOI: 10.2118/107753-MS.

[18] Xian-yu Yang, Ye Yue, Ji-hua Cai, Yue Liu, Xiao-ming Wu: Experimental study and stabilization mechanisms of silica nanoparticles based brine mud with high temperature resistance for horizontal shale gas wells. Journal of Nanomaterials 2015, s. 1-9, DOI: 10.1155/2015/745312.

[19] Youping Wu, Qing Qi, Gui-Hua Liang, Li-Qun Zhang: A strategy to prepare high performance starch/rubber composites: In situ modification during latex compounding process. Carbohydrate Polymers 2006, vol. 65, no. 3, s. 109-113, DOI: 10.1016/j. carbpol.2005.12.031.

[20] Zakaria N.A.: New pore pressure evaluation techniques for LAGIA-8 well, Sinai, Egypt as a case study. International Journal of Geosciences 2016, vol. 7, no. 1, s. 32-46, DOI: 10.4236/ ijg.2016.71004.

[21] Zhang S.F., Qiu Z.S., Huang W.A., Cao J., Tang W.Q., Zhong H.Y.: A Novel Aluminum-based Shale Stabilizer. Petroleum Science and Technology 2013, vol. 31, no. 12, s. 12751282.

[22] Zima G.: Analiza wpływu nanomateriałów na właściwości osadu filtracyjnego. Nafta-Gaz 2017, nr 5, s. 312-320, DOI: 10.18668/NG.2017.05.03.

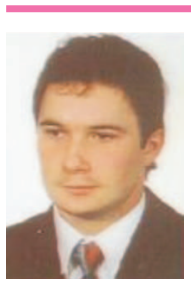

Mgr inż. Sławomir BŁAŻ

Starszy specjalista badawczo-techniczny w Zakładzie Technologii Wiercenia. Instytut Nafty i Gazu - Państwowy Instytut Badawczy ul. Lubicz $25 \mathrm{~A}$

31-503 Kraków

E-mail: slawomir.blaz@inig.pl 